\title{
The Impact of Harvester Calibration on the Accuracy of Birch Veneer Logs Measurements by Measuring Diameter in Short Intervals Using Electronic 3d Systems
}

\author{
Ziedonis Miklašēvičs \\ Rezekne Academy of Technologies, Faculty of Engineering, Environmental Technology Transfer Contactpoint. \\ Address: Atbrivosanas aleja 76, Rezekne, LV-4601, Latvia.
}

\begin{abstract}
Accurate calibration of the harvester head relies on accurate manual log measurements. According to the recommended calibration procedures as proposed by the harvester manufacturer the differences between the volume measurements from harvester measurement system and the caliper-and-tape system must be within $\pm 3 \%$ and harvester diameter measurements within $\pm 6 m m$ of manual measurements in $80 \%$ cases.

Requirements in Latvia stipulate that total volume measurement accuracy levels must be within $\pm 5 \%$ of actual volume if veneer or birch logs are being harvested, $\pm 3 \%$ if saw logs are being harvested and $\pm 10 \%$ if pulp wood or fire wood are being harvested.

The purpose of this study is to assess the impact of harvester calibration on the accuracy of birch veneer logs measurements by Measuring Diameter in Short Intervals using electronic 3D systems when different double bark volume determination algorithm are used in harvester and stacionar measurement system. The research was carried out in December 2016 in the region Latgale in Latvia. The wood felling area was chosen - Mercurialiosa mel. For volume estimation the sequent measurement equipment were applied: harvester Ponsse ERGO $8 \mathrm{~W}$, harvester information system Opti $4 G$ and electronic 3D scanner system Elmes 3600.

The research is a continuation to the work done in the project „Harmonisation of piece-by-piece measurement methods of roundwood approved by Standard LVS 82:2003 „Apaḷo kokmateriälu uzmērišsana” [6], the project "Harmonization of piece-by-piece measurement methods in all stages of roundwood manufacturing processes" [7] and the project "Investigation and evaluation of the methodology of determination of solid volume according to the stacked volume on roadside and in forwarder loads for logistics purposes in LATVIA" [8].
\end{abstract}

Keywords: Harvesters; calibration; measurement accuracy, veneer logs, volume.

\section{INTRODUCTION}

Sawmills orders for roundwood assortiments from the woods are being made by increasingly tight specifications. A $\log$ that has been harvested in a specified lenght and diameter in the wood felling place often ends up in a different diameter class at the sawmill. Thus the quantities of logs in the specified classes delivered to the mill often fail to meet the specification. The main reasons are sequental:

1. Harvester measuring system doesn`t work correctly.

In order to ensure that the harvester systems for measuring roundwood lenght, diameter are accurate, the harvester control and calibration procedures are applied making random control measurements of a number of stems and comparing the results with the machine data. In Latvian forest industry the methodology of harvester calibration is based on StanFord standard [10]. According to the standard, the analysis of harvester measuring system accuracy has been made using harvester calibration and control measurement Ktr-file.

An independent auditor monitors the results continually and visits every harvester a number of times a year to verify that the specified procedures are being followed.

In Finland data from these measurement systems are used as a basis for optimising machine yield and assortment mix, payment of contractors, payment of timber growers and the monitoring of operators [5].

What does it mean "well calibrated harvester measurement system"?

In Ireland volume accuracy levels of $6.7 \%$ for a clearfell site and $5.3 \%$ for a thinning site are determined [9].

Harvester calibration requirements in Latvia stipulate that volume estimates of control roundwood assortiments must be within $\pm 3 \%$ of the true volume and at least $80 \%$ of all diameter measurements shouldn't exceed $\pm 6 \mathrm{~mm}$ deviation. 
2. Measurement requirements used by the harvesters differ from those used by the mills.
The analyses of roundwood measurement requirements used in harvester measuring systems $[1 ; 2 ; 3 ; 4 ; 11 ; 12 ; 13]$ are given (Table 1$)$.

Table 1

The Measurement Requirements Used in Harvester Measuring Systems

\begin{tabular}{|c|c|c|c|c|c|c|c|c|c|c|c|}
\hline \multirow{2}{*}{ VariablesB 2:055 } & \multirow{2}{*}{ Criteria } & \multicolumn{10}{|c|}{ Countries } \\
\hline & & Swe $_{\text {sub }}$ & Swe to & Fin $_{\text {sob }}$ & Nor $_{\text {mid }}$ & Ger $_{\text {mid }}$ & $\mathrm{Ger}_{\text {top }}$ & Dan $_{\text {mid }}$ & Est $_{\text {mid }}$ & $\mathrm{Fra}_{\text {sub }}$ & Latvia* sub \\
\hline $\begin{array}{l}\text { Diameters in Diameter Classes } \\
\text { (price matrix) }\end{array}$ & $\begin{array}{l}1=\text { Top } \\
2=\text { Midpoint }\end{array}$ & 1 & 1 & 1 & 1 & 2 & 1 & 2 & 1 & 1 & 1 \\
\hline Diameter Class Adjust & $\begin{array}{l}1=\text { diameter class smaller or equal to log diameter } \\
2=\text { closest diameter class, normal rounding }\end{array}$ & 1 & 1 & 1 & 1 & 1 & 1 & 1 & 1 & 1 & 1 \\
\hline Diameter Classes under bark & True/False & TRUE & TRUE & FALSE & TRUE & TRUE & TRUE & FALSE & TRUE & TRUE & TRUE \\
\hline \begin{tabular}{|l|}
$\begin{array}{l}\text { Position from top end of log } \\
\text { where top diameter is measured }\end{array}$ \\
\end{tabular} & $\mathrm{Cm}$ & 10 & 10 & 0 & 10 & 0 & 0 & 0 & 0 & 0 & 10 \\
\hline Lenght Class Adjust & $\begin{array}{l}1=\text { lenght class smaller or equal to log diameter } \\
2=\text { closest lenght class, normal rounding }\end{array}$ & 1 & 1 & 1 & 1 & 1 & 1 & 1 & 1 & 1 & 1 \\
\hline $\begin{array}{l}\text { Diameters in log price volume } \\
\text { calculation }\end{array}$ & $\begin{array}{l}1=\text { measured diameter } \\
2=\text { measured diameter rounded down to } \mathrm{cm}\end{array}$ & 1 & 1 & 1 & 1 & 1 & 1 & 1 & 1 & 1 & 1 \\
\hline $\begin{array}{l}\text { Diameters used in log price } \\
\text { volume calculation }\end{array}$ & $\begin{array}{l}1=\text { Solid volume } \\
2=\text { Top } \\
3=\text { Mid } \\
4=\text { Calculated Norwegian mid } \\
5=\text { Calculated Estonian mid } \\
\end{array}$ & 1 & 2 & 1 & 4 & 3 & 3 & 3 & 5 & 1 & 1 \\
\hline $\begin{array}{l}\text { Lenghts used in price volume } \\
\text { calculation }\end{array}$ & $\begin{array}{l}1=\text { =Physical lenght } \\
2=\text { Lenght as defined in Lenght } \\
\text { Classes } \\
3=\text { Rounded dounwards to } \\
\text { nearest dm-module } \\
4=\text { Rounded to nearest dm-module } \\
\end{array}$ & 1 & 2 & 1 & 3 & 2 & 2 & 1 & 1 & 1 & 2 \\
\hline Price volume under bark & True/False & TRUE & TRUE & FALSE & TRUE & TRUE & TRUE & FALSE & TRUE & TRUE & TRUE \\
\hline $\begin{array}{l}\text { Position from top end of log } \\
\text { where top diameter for log } \\
\text { volume calculation is measured }\end{array}$ & $\mathrm{Cm}$ & 10 & 10 & 0 & 10 & 0 & 0 & 0 & 0 & 0 & 10 \\
\hline Bark Function Category & 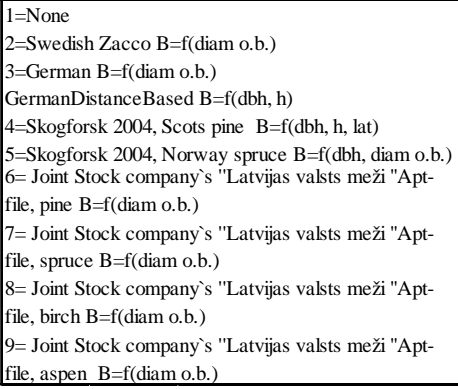 & $2 ; 4 ; 5$ & $\begin{array}{c}2 ; 4 \\
5\end{array}$ & 1 & $2 ; 4 ; 5$ & 3 & 3 & 1 & $2 ; 4 ; 5$ & $2 ; 4$ & $\begin{array}{c}0 ; 6 ; 7 ; 8 \\
9\end{array}$ \\
\hline
\end{tabular}

3. Diameter (under bark) measuring technique used in the mills is not the same as that used by the harvesters.

Inspite of calibration of the harvester measuring system using individual logs is very accurate, the volume meaurement results are unsatisfactory when comparing the volume calculation results obtained in harvester and stacionar measurement equipment in sawmill. The differences between the harvester measurements and the stacionar measurement equipment measurements fluctuate, varrying from positive to negative volume values. These differences could be explained with the methodical procedure based on different and variet criteria.

One of the criteria is bark thickness estimation methodology. Harvester measurement system calculate double bark thickness from diameter over bark and use the results to estimate roundwood assortiment diameter and volume under bark (u.b.).
For birch logs and veneer logs the double bark thickness at the point of measuring is determined in Apt-file by using the sequential formula (1).

$$
\mathrm{B}=3,45+0,0404 \times \mathrm{D}
$$

where: D - diameter of roundwood assortiment over bark (o.b.), mm.

In veneer mill each veneer $\log$ is appreciated according to bark amount (\%) and diameter ( $\mathrm{mm}$ ) coherence (Table 2.) and bark's presence on log surface. If the bark presence on log is less than $50 \%$, the $\log$ is measured without bark.

The corresponding variables related to the investigation are defined below:

Apt-file Bucking(cross-cutting) instructions

DBH $\left(\mathrm{d}_{1.2}\right)$ The first measuring point done by harvester measuring system for butt diameter prediction 
Environment. Technology. Resources, Rezekne, Latvia Proceedings of the $11^{\text {th }}$ International Scientific and Practical Conference. Volume III, 217-221

Ktr-file Harvester calibration and control measurement file. Sent from digital callipers to (on-board) merchandishing (bucking) computer, and from merchandishing computer to the office computer

Mercurialiosa mel. Woodlands on drained mineral

Prd-file Production of the harvester (measurement certificate)

Pri-file Production-individual. Data of each log made from the site

Table 2.

Bark Amount (\%) and Diameter (mm) Coherence

\begin{tabular}{ccc}
\hline Bark amount,\% & Diameter $\mathbf{m i n}$. (mm) & Diameter max. $(\mathbf{m m})$ \\
\hline 12 & 0 & 190 \\
\hline 11 & 190.1 & 230 \\
\hline 10 & 230.1 & 390 \\
\hline 9 & 390.1 & 999 \\
\hline
\end{tabular}

\section{MATERIALS AND METHODS}

The wood felling area (Fig. 1.) was chosen Mercurialiosa mel. The study was carried out in december 2016 in the region Latgale in Latvia. The wood falling time was chosen because of the minimal risk of debarking in the process of harvesting.

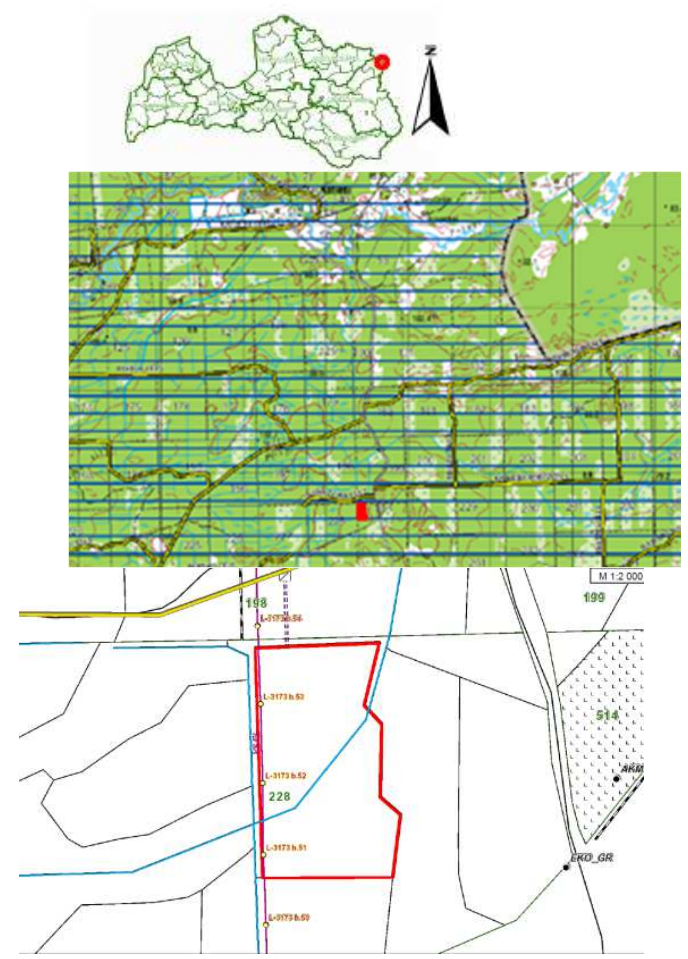

Fig. 1. Wood felling area and the technological scheme of harvesting, where species of a trees: $10 \%$ pine, $20 \%$ spruce, $70 \%$ birch

The following procedures were used to achieve the required objective:

To control the measurement accuracy of harvester Ponsse ERGO 8W measuring systems and electronic 3D scanner system Elmes 3600.
1. To identify the birtch stems before harvesting and all veneer logs after harvesting.To measure the identified veneer $\operatorname{logs}$ by measuring diameter in short intervals using electronic 3D systems.

2. To collect and analyse the harvester mesurement Pri-file data in connection with automatically measured parameters of veneer logs.

3. To analyse the measurement results.

The following measurement methods were applied in the investigation:

1. Individual measurement method by measuring diameter in short intervals using harvester measurement system.

2. Individual measurement method by measuring diameter in short intervals using electronic 3D system.

The following equipment were applied in the experimental investigation:

manual measuring equipment; harvester Ponsse ERGO $8 \mathrm{~W}$, harvester information system Opti $4 G$ and electronic 3D scanner system Elmes 3600.

The object of the investigation were assortiments harvested according to the specification (Table 3.).

Table 3

Specification of Birch Veneer Logs

\begin{tabular}{ccccc}
\hline $\begin{array}{c}\text { Assortiment, } \\
\mathbf{~ m m}\end{array}$ & $\begin{array}{c}\text { Identification of } \\
\text { the top diameter, } \\
\mathbf{m m}\end{array}$ & $\begin{array}{c}\text { Top diameter } \\
(\mathbf{m i n} / \mathbf{m a x}), \mathbf{m m}\end{array}$ & Nominal lenght, $\mathbf{m}$ & $\begin{array}{c}\text { Max. } \\
\text { diame ter, } \mathbf{m m}\end{array}$ \\
\hline $120 \times 139$ & $120-139$ & $130 / 139$ & 4.8 & 700 \\
\hline $140 \times 159$ & $140-159$ & $140 / 159$ & 4.8 & 700 \\
\hline $160 \times 179$ & $160-179$ & $160 / 179$ & 4.8 & 700 \\
\hline $180 \times 209$ & $180-209$ & $180 / 209$ & 4.8 & 700 \\
\hline $210 \times 249$ & $210-249$ & $210 / 249$ & 4.8 & 700 \\
\hline $250-299$ & $250-299$ & $250 / 299$ & 4.8 & 700 \\
\hline $300-399$ & $300-399$ & $300 / 399$ & 4.8 & 700 \\
\hline $400<$ & 400 & $400 / 700$ & 4.8 & 700 \\
\hline
\end{tabular}

III. RESULTS AND DISCUSSION

Harvester measurement accuracy were assessed through comparison with manual log measurements and volume calculation according to the schemes (Fig.2.,3.,4.)

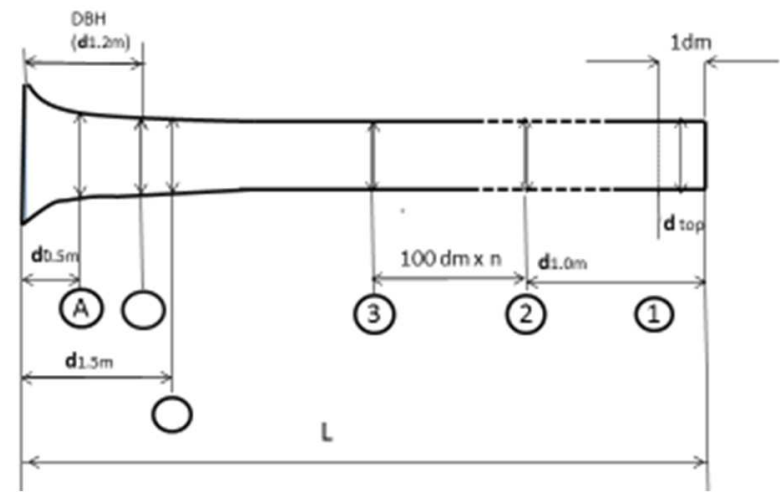

Fig. 2. The scheme of measuring points for logs from neiloid zone of stem in the process of harvester Ponsse ERGO 8W measurement system controlling, where:

$\mathrm{DBH}(\mathrm{d} 1.2 \mathrm{~m})$ - the first measuring point done by harvester measuring system for butt diameter prediction; A - the last manual control measuring point $(\mathrm{A}=50 \mathrm{dm})$ 


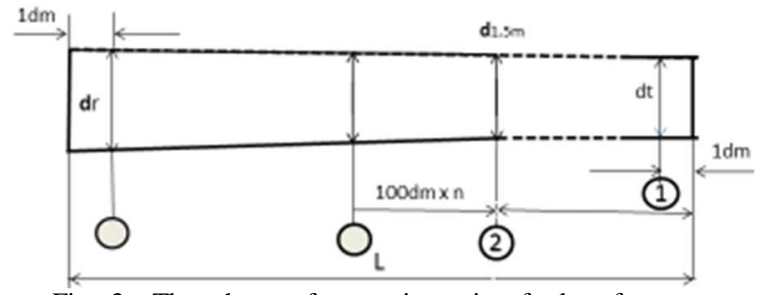

Fig. 3. The scheme of measuring points for logs from paraboloid zone of stem in the process of harvester Ponsse ERGO $8 \mathrm{~W}$ measurement system controlling
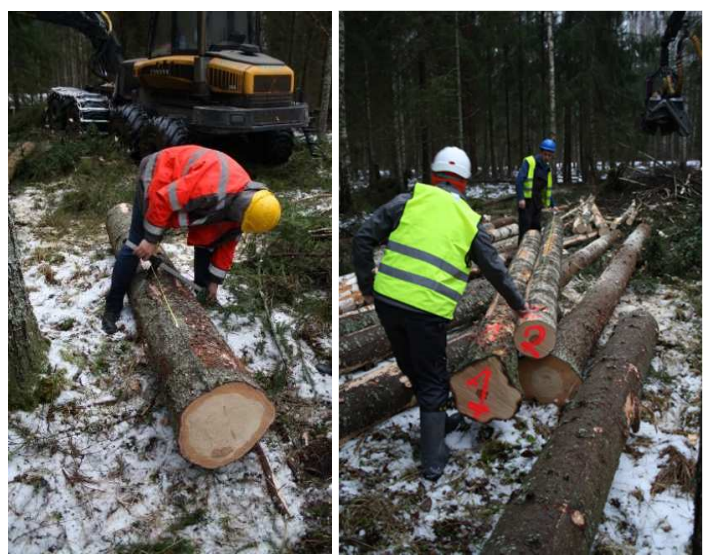

Fig. 4. The control of the harveaster Ponsse ERGO $8 \mathrm{~W}$ measuring system by independent auditor, where:

volume of the control assortiments measured by harvester measurement system $5.430 \mathrm{~m}^{3}$; volume of the control assortiments measured by caliper $5.426 \mathrm{~m}^{3}$; volume deviation $0.1 \% ; 49 \%$ of all diameter include in $\pm 2 \mathrm{~mm}$ deviation; $79 \%$ of all diameter include in $\pm 4 \mathrm{~mm}$ deviation; $93 \%$ of all diameter include in $\pm 6 \mathrm{~mm}$ deviation

All veneer logs were identified in the process of harvesting (Fig.5.), collected in the load (Fig.6.) and measured by measuring diameter in short intervals using electronic 3D systems (Fig.7).

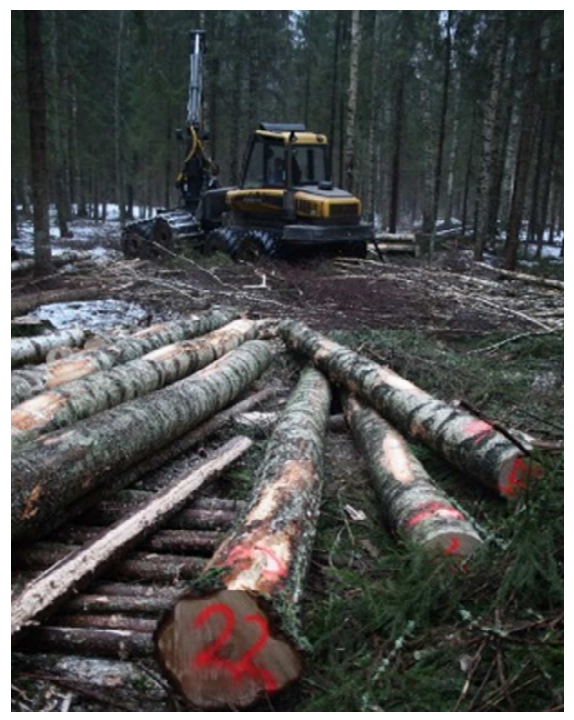

Fig. 5. The example of identified veneer $\operatorname{logs} \mathrm{N}^{\circ} 22 ; 23 ; 24$

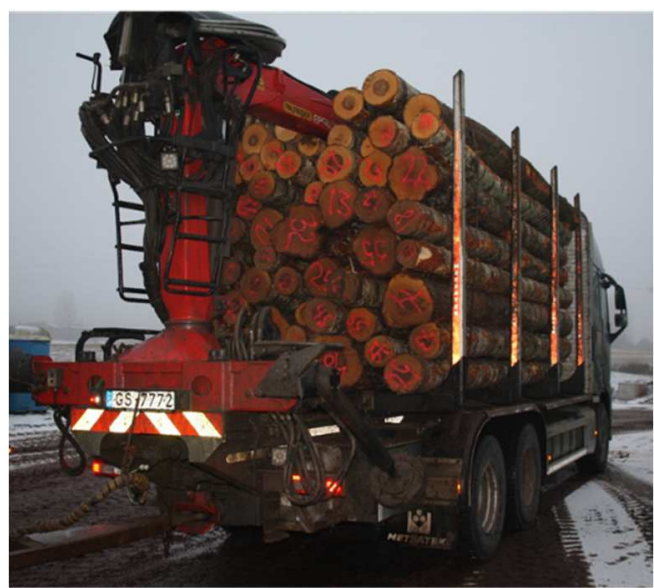

Fig. 6. The load of identified veneer logs
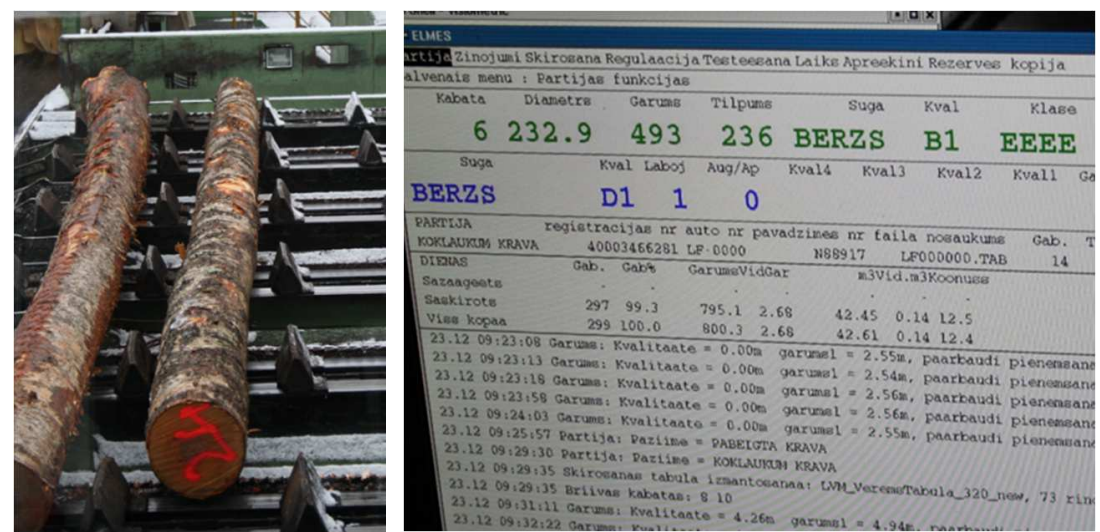

Fig. 7. The example of measuring process and measurement results of identified veneer $\log \mathrm{N}^{\circ} 24$ using 3D scanner systemElmes 3600 , where: actual lenght $(\mathrm{cm}) 493$; nominal lenght $(\mathrm{cm})$ 480; top diam.u.b. $(\mathrm{mm}) 232.9$; actual volume u.b. $\left(\mathrm{m}^{3}\right)$ 0.236; nominal volume u.b. $\left(\mathrm{m}^{3}\right)$ 0.230

All harvester measurement results were collected using Pri-file data (Fig.8.) and analyzed (Table 3) in connection with automatically measured parameters of veneer logs.
The measurement results of the investigation are given (Table 4.) 
Environment. Technology. Resources, Rezekne, Latvia Proceedings of the $11^{\text {th }}$ International Scientific and Practical Conference. Volume III, 217-221

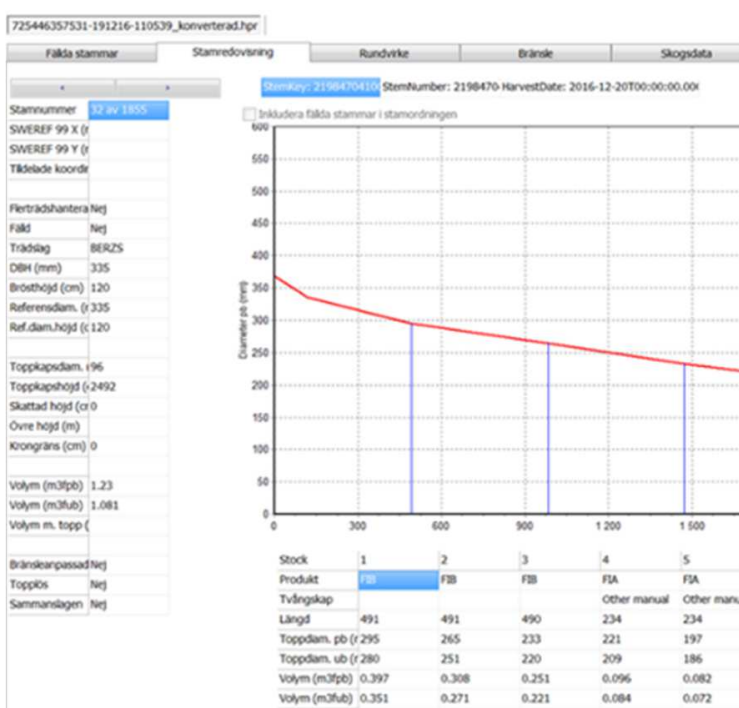

Fig. 8. The example of the measurement results of the stem and identified veneer $\operatorname{logs} \mathrm{Nr} .22 ; 23 ; 24$ in Pri- file, where:

birch stem DBH (mm) 335; birch stem volume ( $\mathrm{m}^{3}$ fub) 1.081 ; veneer $\log \mathrm{Nr} .22$ - lenght 491(cm); top diam.u.b.(mm) 280; volume u.b. $\left(\mathrm{m}^{3}\right)$ 0.351; veneer log Nr.23- lenght 491(cm); top diam.u.b.(mm) 251; volume u.b. $\left(\mathrm{m}^{3}\right)$ 0.271; eneer $\log \mathrm{Nr} .24-$ lenght 490(cm); top diam.u.b.(mm) 209; volume u.b. $\left(\mathrm{m}^{3}\right) 0.221$

Table 4.

The Measurement Results

\begin{tabular}{|lc|}
\hline Variable & Measurements \\
\hline Number of veneer logs & 50 \\
\hline Amount of butt assortiments, \% & 36 \\
\hline Neto volume by harvester, $\mathrm{m}^{3}$ (u.b.) & 13.397 \\
\hline Actual volume by 3D scanner, $\mathrm{m}^{3}$ (u.b.) & 13.819 \\
\hline Neto volume by 3D scanner, $\mathrm{m}^{3}$ (u.b.) & 13.484 \\
\hline DBH (1.2m), mm & 309.8 \\
\hline Average & 316.5 \\
\hline Median & \\
\hline Lenght, cm & 491 \\
\hline Average & 491 \\
\hline Median & 2.08 \\
\hline Standard deviation & 0.29 \\
\hline Standard error & \\
\hline Diameter, mm & 245.3 \\
\hline Average & 246.5 \\
\hline Median & 6.1 \\
\hline Standard deviation & 0.86 \\
\hline Standard error & \\
\hline Volume, $\mathrm{m}^{3}$ & 0.267 \\
\hline Average & 0.253 \\
\hline Median & 3.6 \\
\hline Standard deviation, \% & 0.5 \\
\hline Standard error, \% \\
\hline
\end{tabular}

IV. CUNCLUSION

1. No clear effect of calibration can be detected on diameter measurements due to different approach of double bark thickness calculculation. Diameter standard deviation reaches $6.1 \mathrm{~mm}$ if the harvester measuring system calculates diameters (u.b.) using double bark function (1), but electronic 3D scanner system uses bark amount (\%) and diameter (mm) coherence (Table 2).

2. Standard deviation reaches $3.6 \%$ if volume of veneer logs (u.b.) are calculated using different double bark calculation methods.

3. Standard deviation reaches $2.08 \mathrm{~cm}$ in lenght measurements.

\section{REFERENCES}

[1] Apalo kokmateriālu uzmērǐšana. LVS 82:2003.

[2] Anon 2000. Kompendium i virkesmätning. Virkesmätningsrådet, SDC, Sundvall.

[3] Arlinger, J. and Moller, 1. J. Kvalitetssäkring av skördarnas mätning. Skogforsk Results No.20.2006. Skogforskhttp://www.skogforsk.se/contentassets/3a3c190011 e241d5a92e22ee8c26a598/resultat20--06-lowres.pdf

[4] European Forest Sector Outlook Study 1960-2000-2020: Main Report (UNECE/FAO). 2005. http://www. unece.org/timber/efsos/data/conversion-factors.pdf.

[5] Gingras, J-F. Recent Developments in Chip Cleaning and Cut-To-Length Harvesting Technologies in Finland. Forest Engineering Research Institute of Canada (FERle)Eastern Division, Internal Report IR-1995-06-01.

[6] Miklasevics, Z. Harmonization of piece-by-piece measurement methods of roundwood approved by Latvian standard LVS 82:2003 "Apaḷo kokmateriālu uzmērīšana". ISSN 1691-5402. Environment. Technology. Resources. Proceedings of the $9^{\text {th }}$ international conference reports, Rezekne. 2013,pp. 154-163

[7] Miklasevics, Z. Harmonization of piece-by-piece measurement methods in all stages of roundwood manufacturing processes". ISSN 1691-5402. Environment. Technology. Resources. Proceedings of the $10^{\text {th }}$ international conference reports, Rezekne, 2015. pp. 207-218.

[8] Miklasevics, Z. Investigation and evaluation of the methodology of determination of solid volume according to the stacked volume on roadside, in forvarder and in truck loads for logistics purposes in Latvia.//The $49^{\text {th }}$ FORMEC Symposium, Warsaw, Poland 2016, pp. 89-98

[9] Nieuwenhuis, M. and Dooley, T. 2006. The effect of Calibration on the Accuracy of HarvesterMeasurements. International Journal of Forest Engineering. 17(2). 2006, pp. 25-33.

[10] Räsänen, T., Poikela, A., Arlinger, J. 2010. Spp-file in StanForD. http://www.skogforsk.se/en/Aboutskogforsk/Collaboration-groups/StanForD/StandardDocuments/

[11] Standard procedures for checking timber measurement and timber reporting. 2015. SDC's instructions for timber measurement. http://www.sdc.se/default.asp?id=3005

[12] Timber measurement manual. Standard procedures for the measurement of round timber for sale purposes in Ireland. 1999.

http://www.coford.ie/media/coford/content/publications/proj ectreports/TimberMeasurementManual.pdf

[13] Sondell, J., Moller, 1. J. and Arlinger, J. Thirdgeneration merchandiSing computers. Skogforsk Results No.2. 2002. 